\title{
The Usability of Electronic Medical Record Systems Implemented in Sub-Saharan Africa: A Literature Review of the Evidence
}

\author{
Michael Kavuma ${ }^{1,2}$, BSc, MMedSci \\ ${ }^{1}$ Department of Tele-Health, College of Health Sciences, University of KwaZulu-Natal, Durban, South Africa \\ ${ }^{2}$ MedLite Systems Limited, Kampala, Uganda
}

\section{Corresponding Author:}

Michael Kavuma, BSc, MMedSci

Department of Tele-Health

College of Health Sciences

University of KwaZulu-Natal

Nelson R Mandela School of Medicine

719 Umbilo Road 4001, Congella 4013

Durban,

South Africa

Phone: 27782632775

Email: mikavs@gmail.com

\begin{abstract}
Background: Electronic medical record (EMR) systems hold the exciting promise of accurate, real-time access to patient health care data and great potential to improve the quality of patient care through decision support to clinicians. This review evaluated the usability of EMR systems implemented in sub-Saharan Africa based on a usability evaluation criterion developed by the Healthcare Information and Management Systems Society (HIMSS).

Objective: This review aimed to evaluate EMR system implementations in sub-Saharan Africa against a well-defined evaluation methodology and assess their usability based on a defined set of metrics. In addition, the review aimed to identify the extent to which usability has been an enabling or hindering factor in the implementation of EMR systems in sub-Saharan Africa.

Methods: Five key metrics for evaluating EMR system usability were developed based on the methodology proposed by HIMSS. These were efficiency, effectiveness, ease of learning, cognitive load, and user satisfaction. A 5-point rating system was developed for the review. EMR systems in 19 reviewed publications were scored based on this rating system. It awarded 5 points per metric to any EMR system that was identified as excellent, 4 points for good, 3 points for fair, 2 points for poor, and 1 point for bad. In addition, each of the 5 key metrics carried a maximum weighted score of 20 . The percentage scores for each metric were then computed from the weighted scores from which the final overall usability score was derived.

Results: In possibly contributing to the usability of implemented EMR systems, ease of learning obtained the highest percentage score of $71 \%$ (SD 1.09) followed by cognitive load in second place with a score of $68 \%$ (SD 1.62). Effectiveness followed closely in third place at 67\% (SD 1.47) and efficiency was in fourth place at 64\% (SD 1.04). User satisfaction came in last at 63\% (SD 1.70). The overall usability score for all systems was calculated to be $66 \%$.

Conclusions: The usability of EMR systems implemented in sub-Saharan Africa has been good with ease of learning possibly being the biggest positive contributor to this rating. Cognitive load and effectiveness have also possibly positively influenced the usability of EMR systems, whereas efficiency and user satisfaction have perhaps contributed least to positively influencing EMR system usability.
\end{abstract}

(JMIR Hum Factors 2019;6(1):e9317) doi: 10.2196/humanfactors.9317

\section{KEYWORDS}

review; computer systems; delivery of health care; sub-Saharan Africa 


\section{Introduction}

\section{Background}

The free dictionary defines an electronic medical record (EMR) as a repository for active notations about a patient's health; it is a computerized database that typically includes demographic, medical, laboratory, radiographic, drug, and other information about a patient [1]. EMR systems have evolved from pure record keeping to integrated enterprise-wide systems that hold the promise of accurate, real-time access to patient health care data while providing information necessary to improve patient care and lower costs [2]. Many institutions are developing integrated clinical workstations, which provide a single point of entry for access to patient-related, administrative, and research information. At the heart of the evolving clinical workstation lies the medical record in a new incarnation: electronic, accessible, confidential, secure, acceptable to clinicians and patients, and integrated with other nonpatient specific information [3].

EMR systems have also been shown to improve the quality of disease management, prevent disease-related comorbidities in hospitals [4], and to substantially reduce the risk of medication errors and adverse drug events [5]. They can significantly improve clinical documentation and medication refill turnaround time [6] and are perceived by physicians to have a positive impact on the quality of patient care [7]. The entire health care system can benefit immensely from the use of EMR systems with tangible benefits in cost savings and patient safety [8], making them especially relevant for low resource settings.

In Africa, electronic health care information systems have been driven mainly by the need to report aggregate statistics for government or funding agencies [9]. The use of computerized patient management systems is grossly limited in Africa where paper-based systems are still predominantly used in health care delivery. Some initiatives have been taken to deploy EMR systems though their focus has been heavily on HIV/AIDS care [10] and other infectious disease programs.

The Healthcare Information and Management Systems Society (HIMSS) defines a set of principles and methods for testing and evaluating EMR usability. It defines usability as the effectiveness, efficiency, and satisfaction with which specific users can achieve a specific set of tasks in a particular environment [11]. They submit that usability is possibly one of the most important factors hindering widespread adoption of EMRs and often has a strong direct relationship with clinical productivity, error rate, user fatigue, and user satisfaction. This literature review aimed at evaluating the usability of EMR systems implemented in sub-Saharan Africa using the usability evaluation criterion developed by HIMSS to identify the extent to which usability has enabled or hindered adoption of EMR systems in sub-Saharan Africa.

\section{Objectives}

The objectives of the literature review were the following:

1. To evaluate EMR system implementations in sub-Saharan Africa against a well-defined evaluation methodology and assess their usability based on a defined set of metrics
2. To identify the extent to which usability has been an enabling or hindering factor in the implementation of EMR systems in sub-Saharan Africa

\section{Methods}

\section{Evaluation Metrics}

This literature review assessed EMR systems implemented in a sub-Saharan African context, using the evaluation methods and metrics proposed by HIMSS. HIMSS defines principles and proposes methods for evaluating and rating EMR usability. Its principles for good usability of EMR systems include simplicity, which refers to lack of visual clutter, concise information display, inclusion of only functionality that is needed to effectively accomplish tasks; they include naturalness, which refers to how automatically familiar and easy-to-use the application feels to the user; they also include consistency, which refers to how much an applications structure, interactions, and behaviors match a user's experience with other software applications and how an application uses concepts, behavior, appearance and layout consistently throughout.

The principles also include minimizing cognitive overload by presenting all the information needed for the task at hand and displaying information organized by meaningful relationships: efficient interactions within the system, which refers to minimizing the number of steps it takes to complete tasks and providing shortcuts to experienced users and frequently used functions, incorporating forgiveness and feedback within the EMR system design, effective use of language in a form that is concise and unambiguous, effective information presentation in the appropriate density, and preservation of context by keeping screen changes and visual interruptions to a minimum.

From these principles, HIMSS proposes $5 \mathrm{key}$ metrics for evaluating EMR system usability. These include efficiency, effectiveness, ease of learning, cognitive load, and user satisfaction. Efficiency as a test metric is defined as the speed at which a user can successfully accomplish the task at hand within the EMR system, whereas effectiveness is defined as the accuracy and completeness with which a user can achieve task goals within the EMR system. Ease of learning is defined as the time it takes a user to reach a specified level of proficiency in the use of the EMR system, whereas cognitive load is defined by how intuitively information and functionality are presented within the application, minimizing thought interruptions to users as they perform tasks within the software application. User satisfaction is defined as a person's subjective response to his or her interaction with the EMR system, and it can be evaluated through a Likert-scale rating system or system usability scale questionnaires.

\section{Review Rating System}

A 5-point rating system was developed for this review to rate instances of EMR systems implemented in sub-Saharan Africa based on the 5 key metrics mentioned above. The rating for this review weighted all 5 metrics equivalently in determining usability of EMR systems. Table 1 shows the applied rating per metric in the testing of EMR system usability. 
Table 1. Key usability metrics used for the literature review and their maximum assigned weighted scores along with the 5-point rating system.

\begin{tabular}{lll}
\hline Key usability metric & Maximum weighted score & 5-point individual usability rating for all metrics \\
\hline Effectiveness & 20 & Excellent=5 points; Good=4 points; Fair=3 points; Poor=2 points; Bad=1 point \\
Efficiency & 20 & Excellent=5 points; Good=4 points; Fair=3 points; Poor=2 points; Bad=1 point \\
Ease of learning & 20 & Excellent=5 points; Good=4 points; Fair=3 points; Poor=2 points; Bad=1 point \\
User satisfaction & 20 & Excellent=5 points; Good=4 points; Fair=3 points; Poor=2 points; Bad=1 point \\
Cognitive load & 20 & Excellent=5 points; Good=4 points; Fair=3 points; Poor=2 points; Bad=1 point \\
Total & 100 & $-{ }^{a}$ \\
\hline
\end{tabular}

${ }^{\mathrm{a}}$ Not applicable.

For each of the 5-key metrics, a 5-point usability rating was applied to each individual metric and EMR systems rated based on how the authors of a publication about an EMR system described the performance of the system in their publication. For instance, if an EMR system was described as being excellent for any of the key usability metrics, then that EMR system was rated with 5 points for that metric. If it was described as good by the authors, then it was rated with 4 points, fair with 3 points, poor with 2 points, and bad with 1 point.

To illustrate, if an EMR system's effectiveness was described as being excellent by the authors, then a usability rating of 5 points was assigned to that system's publication for effectiveness. If the same system's ease of learning was defined as poor by the authors, then the same system was assigned a usability rating of 2 points for ease of learning. Therefore, the highest usability rating that was attainable for any key metric was 5 , whereas the lowest was 1 . The search keywords and phrases were scored against this 5-point rating system in a uniform manner across all 5 metrics. Table 2 shows the uniform rating applied to keywords in the review.
In addition, in the methodology developed for this review, each metric carried a maximum weighted score of 20 per reviewed system, that is, effectiveness 20 , efficiency 20 , ease of learning 20 , user satisfaction 20, and cognitive load 20. The rating for each system in each key metric was then computed as a score of the weight of that metric, that is, if a system was rated as fair in effectiveness by the authors, it was assigned a usability rating of 3 for effectiveness equating to a weighted score of $(3 / 5) \times 20=12$ for effectiveness. The same rating and scoring system was assigned to EMR system publications across all 5 key usability metrics.

The total score for all reviewed systems in each metric was then computed by summing up the weighted scores of the systems scored for that metric. The number of systems scored per metric was noted and the maximum attainable total score per metric was then calculated by multiplying the maximum weighted score of that metric by the number of systems scored in that metric. The percentage score for each metric was then calculated by dividing the total weighted score of that metric by the maximum attainable total score of the same metric and multiplying the result by $100 \%$.

Table 2. Uniform rating of keywords against the 5-point rating system.

\begin{tabular}{|c|c|c|c|c|c|}
\hline $\begin{array}{l}\text { Scoring of search } \\
\text { keywords }\end{array}$ & Effectiveness & Efficiency & Ease of learning & User satisfaction & Cognitive load \\
\hline Excellent $=5$ points & $\begin{array}{l}\text { Enhanced patient care } \\
\text { and management }\end{array}$ & $\begin{array}{l}\text { Totally eliminated de- } \\
\text { lays }\end{array}$ & Quick user proficiency & $\begin{array}{l}\text { Preferred system, } \\
\text { viewed system as essen- } \\
\text { tial }\end{array}$ & $\begin{array}{l}\text { Inclusion of standard } \\
\text { treatment guidelines }\end{array}$ \\
\hline Good $=4$ points & $\begin{array}{l}\text { Significant improve- } \\
\text { ment and system indis- } \\
\text { pensable }\end{array}$ & $\begin{array}{l}\text { Reduced patient or } \\
\text { provider burden }\end{array}$ & $\begin{array}{l}\text { User friendly interfaces, } \\
\text { easy to comprehend, } \\
\text { similarity with paper } \\
\text { forms }\end{array}$ & $\begin{array}{l}\text { Happy with system, us- } \\
\text { er enthusiasm, rely on } \\
\text { system, many perceived } \\
\text { benefits from system } \\
\text { use }\end{array}$ & $\begin{array}{l}\text { Easily discerned func- } \\
\text { tionality, well orga- } \\
\text { nized information, logi- } \\
\text { cal and systematic doc- } \\
\text { umentation }\end{array}$ \\
\hline Fair $=3$ points & $\begin{array}{l}\text { Effective, met objec- } \\
\text { tives, improved data } \\
\text { quality or records avail- } \\
\text { ability, decision support }\end{array}$ & $\begin{array}{l}\text { Efficient, reduced time, } \\
\text { streamlined procedures, } \\
\text { and improved workflow }\end{array}$ & $\begin{array}{l}\text { Easy to learn, simple, } \\
\text { easy to use, and lan- } \\
\text { guage customization }\end{array}$ & $\begin{array}{l}\text { User satisfaction, ac- } \\
\text { ceptability, some bene- } \\
\text { fits from use, limited } \\
\text { adoption challenges }\end{array}$ & $\begin{array}{l}\text { Intuitive, easy access to } \\
\text { system information, and } \\
\text { availability of reports }\end{array}$ \\
\hline Poor $=2$ points & $\begin{array}{l}\text { Functionality limita- } \\
\text { tions and low usage }\end{array}$ & $\begin{array}{l}\text { Increased time or bur- } \\
\text { den }\end{array}$ & Complicated interfaces & $\begin{array}{l}\text { User dissatisfaction and } \\
\text { adoption challenges }\end{array}$ & $\begin{array}{l}\text { Cluttered information } \\
\text { and disorganized infor- } \\
\text { mation }\end{array}$ \\
\hline $\mathrm{Bad}=1$ point & $\begin{array}{l}\text { Did not meet objec- } \\
\text { tives, ineffective, led to } \\
\text { errors }\end{array}$ & Complicated workflow & $\begin{array}{l}\text { Extensive effort to gain } \\
\text { user proficiency }\end{array}$ & $\begin{array}{l}\text { Hated system, per- } \\
\text { ceived no benefit from } \\
\text { use of system }\end{array}$ & $\begin{array}{l}\text { Complicated access to } \\
\text { functionality }\end{array}$ \\
\hline
\end{tabular}


Table 3. Grading ranges for overall electronic medical record system usability.

\begin{tabular}{ll}
\hline Percentage score range & Overall grading \\
\hline $80-100$ & Excellent \\
$60-79$ & Good \\
$40-59$ & Fair \\
$20-39$ & Poor \\
$0-19$ & Bad \\
\hline
\end{tabular}

For example, if the total score for all systems reviewed for effectiveness was calculated to be $\mathrm{x}$ and the number of systems scored for effectiveness was $y$, the maximum attainable total score for effectiveness was calculated as (yx20). The percentage score for effectiveness was then calculated as (x/[yx20])x100\%. The same was applied across all 5 metrics to get the percentage scores for each metric. A 95\% CI was applied to the percentage score of each metric.

The overall usability percentage score for EMR systems implemented in sub-Saharan Africa was then calculated as the sum of the total weighted scores of all 5 metrics divided by the sum of the maximum attainable total scores of all 5 metrics and the result expressed as a percentage. Finally, a predefined grading system of 5 ranges was applied to the overall percentage score to determine the overall usability performance of the reviewed EMR systems. The final overall usability of implemented EMR systems was graded based on Table 3.

\section{Search Criteria}

The literature for this review was obtained from searches in PubMed, Google Scholar, and the directory of open access journals in which 300 articles and literature published between the years 2000 and 2016 were reviewed. Of these, 19 articles were identified to meet the requirements for the literature review and were selected for review. The search terms used for the literature review included the following: implementation of EMR systems in sub-Saharan Africa, evaluation of EMR systems in Africa, computerized patient management systems in Africa, computerized hospital information system in Africa, health information systems in sub-Saharan Africa, testing or implementing electronic health record systems in Africa, and computerized clinic patient system in Africa. Country names from sub-Saharan Africa were also included in the search terms and appended to the ends of the search terms, replacing the words Africa or sub-Saharan Africa for some searches. Google translate was used to translate some French and Portuguese documents. Figure 1 shows a preferred reporting style flow diagram for systematic reviews and meta-analyses, showing the number of articles identified for the review, screened for eligibility, and finally included in the review.

A mixed-methods research approach was adopted for the literature review and involved both qualitative and quantitative research methods. The qualitative aspect focused on identification and extraction of keywords, phrases, and themes related to the 5 key usability metrics from articles included in the final review. The quantitative aspect focused on rating and scoring the systems in these articles using the 5-point rating and weighted scoring systems. Quantitative analysis was subsequently performed on the scores for each system in relation to the research objectives to identify the extent to which usability has been an enabling or hindering factor in the implementation of EMR systems in sub-Saharan Africa. Table 4 lists the 19 publications identified to meet the requirements of the literature review. Multimedia Appendix 1 shows the matching keywords identified in each publication for the 5 metrics. Tables 5 and 6 show the rating and scoring of each of the 19 systems in the 5-key metrics.

Figure 1. Preferred Reporting Items for Systematic Reviews and Meta-Analyses (PRISMA) flow diagram for identification, screening, and final inclusion of articles in the literature review. EMR: electronic medical record.

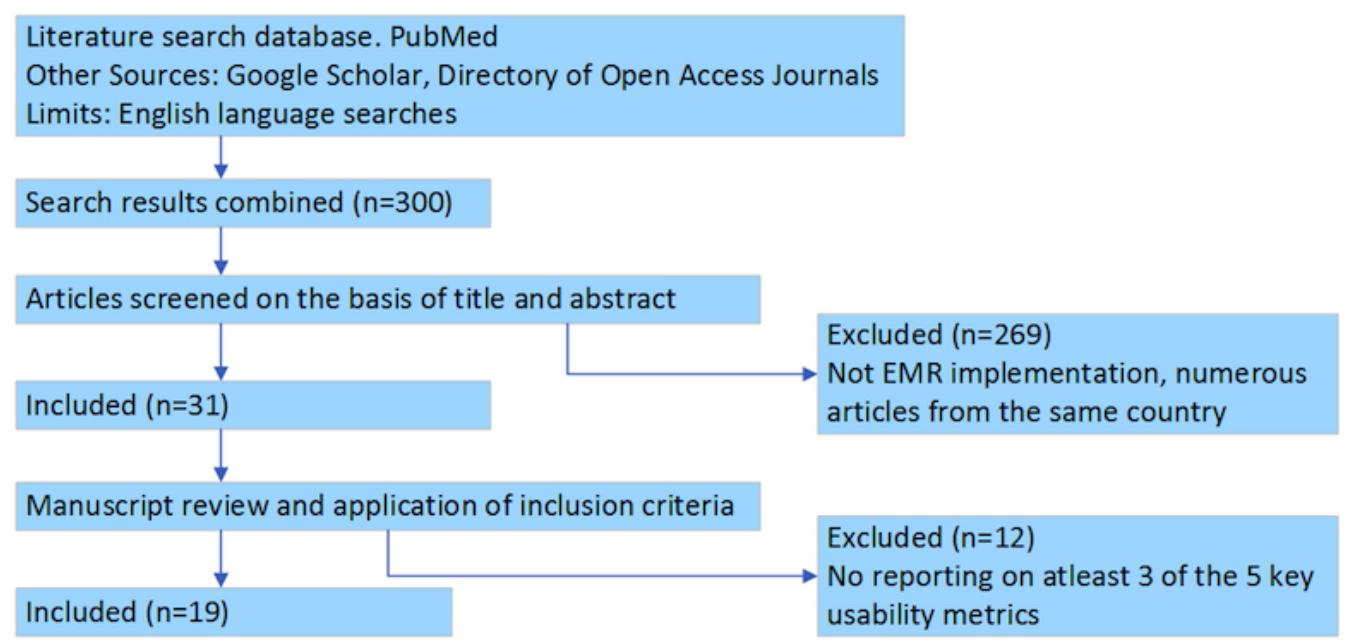


Table 4. List of publications identified to meet the requirements for the literature review.

\begin{tabular}{|c|c|c|c|c|}
\hline Number & Publication & Software & Country & Focus \\
\hline 1 & $\begin{array}{l}\text { A global approach to the management of EMR } \\
\text { (Electronic Medical Records) of patients with } \\
\text { HIV/AIDS in Sub-Saharan Africa: the experi- } \\
\text { ence of DREAM Software [12] }\end{array}$ & DREAMS & $\begin{array}{l}\text { Mozambique; Malawi: Tanzania; Kenya; } \\
\text { Guinea; Republic; Guinea Bissau; } \\
\text { Cameroon; Congo; Democratic Republic } \\
\text { of Congo; Angola; Nigeria }\end{array}$ & HIV/AIDS \\
\hline 2 & $\begin{array}{l}\text { An electronic health record for infertility clinics } \\
\text { [13] }\end{array}$ & EHRIC & South Africa & Reproductive health \\
\hline 3 & $\begin{array}{l}\text { An Electronic Patient Referral Application: A } \\
\text { Case Study from Zambia [14] }\end{array}$ & ZEPRS & Zambia & Perinatal care \\
\hline 4 & $\begin{array}{l}\text { Combining Vital Events Registration, Verbal } \\
\text { Autopsy and Electronic Medical Records in } \\
\text { Rural Ghana for Improved Health Services De- } \\
\text { livery [15] }\end{array}$ & $\begin{array}{l}\text { MGV-Net } \\
\text { VRVA }\end{array}$ & Ghana & Birth registration \\
\hline 5 & $\begin{array}{l}\text { Comprehensive Evaluation of Electronic Medi- } \\
\text { cal Record System Use and User Satisfaction at } \\
\text { Five Low-Resource Setting Hospitals in Ethiopia } \\
\text { [16] }\end{array}$ & SmartCare & Ethiopia & $\begin{array}{l}\text { HIV/AIDS, Tuberculosis, } \\
\text { and Pediatric Care }\end{array}$ \\
\hline 6 & $\begin{array}{l}\text { Designing and implementing an electronic health } \\
\text { record system in primary care practice in sub- } \\
\text { Saharan Africa: a case study from Cameroon } \\
\text { [17] }\end{array}$ & MEDCAB & Cameroon & Primary health care \\
\hline 7 & $\begin{array}{l}\text { Electronic Patient Management System ePMS- } \\
\text { Zimbabwe Collecting and Managing Data at the } \\
\text { Patient Level for Better Treatment and Care [18] }\end{array}$ & ePMS & Zimbabwe & HIV/AIDS and Tuberculosis \\
\hline 8 & $\begin{array}{l}\text { Evaluation of Hospital Information System in } \\
\text { the Northern Province in South Africa [19] }\end{array}$ & HIS & South Africa & General care \\
\hline 9 & $\begin{array}{l}\text { Experience Implementing Electronic Health } \\
\text { Records in Three East African Countries [20] }\end{array}$ & OpenMRS & Kenya; Uganda; Tanzania & HIV/AIDS \\
\hline 10 & $\begin{array}{l}\text { Impact of an electronic clinical decision support } \\
\text { system on workflow in antenatal care: the } \\
\text { QUALMAT eCDSS in rural health care facilities } \\
\text { in Ghana and Tanzania [21] }\end{array}$ & $\begin{array}{l}\text { QUALMAT } \\
\text { eCDSS }\end{array}$ & Ghana; Tanzania & Antenatal care \\
\hline 11 & $\begin{array}{l}\text { Implementation of a Cloud-Based Electronic } \\
\text { Medical Record to Reduce Gaps in the HIV } \\
\text { Treatment Continuum in Rural Kenya [22] }\end{array}$ & $\begin{array}{l}\text { Uamuzi Bo- } \\
\text { ra }\end{array}$ & Kenya & HIV/AIDS \\
\hline 12 & $\begin{array}{l}\text { Implementation of Provider-Based Electronic } \\
\text { Medical Records and Improvement of the } \\
\text { Quality of Data in a Large HIV Program in Sub- } \\
\text { Saharan Africa [23] }\end{array}$ & IDI ICEA & Uganda & HIV/AIDS \\
\hline 13 & $\begin{array}{l}\text { Implementing OpenMRS for patient monitoring } \\
\text { in an HIV/AIDS care and treatment program in } \\
\text { rural Mozambique [24] }\end{array}$ & OpenMRS & Mozambique & HIV/AIDS \\
\hline 14 & $\begin{array}{l}\text { Improvement of Service Capabilities Following } \\
\text { the Establishment of an Electronic Database to } \\
\text { Evaluate AIDS in Central Africa [25] }\end{array}$ & IeDEA DMS & $\begin{array}{l}\text { Burundi; Cameroon; Democratic Republic } \\
\text { of Congo }\end{array}$ & HIV/AIDS \\
\hline 15 & $\begin{array}{l}\text { Integration of ICT In Health Service Manage- } \\
\text { ment in Heal Africa Hospital in DRCongo [26] }\end{array}$ & HEAL HMS & Democratic Republic of Congo & $\begin{array}{l}\text { Primary health care and } \\
\text { general care }\end{array}$ \\
\hline 16 & OpenMRS Ebola Case Study [27] & OpenMRS & Sierra Leone & Ebola \\
\hline 17 & $\begin{array}{l}\text { Scale-up of networked HIV treatment in Nigeria: } \\
\text { Creation of an integrated electronic medical } \\
\text { records system [28] }\end{array}$ & $\begin{array}{l}\text { FileMaker } \\
\text { Pro EMRS }\end{array}$ & Nigeria & HIV/AIDS \\
\hline 18 & $\begin{array}{l}\text { Using Electronic Medical Records for HIV Care } \\
\text { in Rural Rwanda [29] }\end{array}$ & OpenMRS & Rwanda & HIV/AIDS \\
\hline 19 & $\begin{array}{l}\text { Using Touchscreen Electronic Medical Record } \\
\text { Systems to Support and Monitor National Scale- } \\
\text { Up of Antiretroviral Therapy in Malawi [30] }\end{array}$ & POC EMR & Malawi & HIV/AIDS \\
\hline
\end{tabular}


Table 5. Rating of keywords for the 19 systems on the 5 key metrics.

\begin{tabular}{|c|c|c|c|c|c|c|c|c|c|c|}
\hline \multirow[t]{2}{*}{ Publication } & \multicolumn{2}{|c|}{ Effectiveness } & \multicolumn{2}{|c|}{ Efficiency } & \multicolumn{2}{|c|}{ Ease of learning } & \multicolumn{2}{|c|}{ User satisfaction } & \multicolumn{2}{|c|}{ Cognitive load } \\
\hline & Rating $^{\mathrm{a}}$ & $\begin{array}{l}\text { Maximum } \\
\text { Weighted } \\
\text { Score }=20 \\
\text { points }\end{array}$ & Rating $^{\mathrm{a}}$ & $\begin{array}{l}\text { Maximum } \\
\text { Weighted } \\
\text { Score }=20 \\
\text { points }\end{array}$ & Rating $^{\mathrm{a}}$ & $\begin{array}{l}\text { Maximum } \\
\text { Weighted } \\
\text { Score }=20 \\
\text { points }\end{array}$ & Rating $^{\mathrm{a}}$ & $\begin{array}{l}\text { Maximum } \\
\text { Weighted } \\
\text { Score }=20 \\
\text { points }\end{array}$ & Rating $^{\mathrm{a}}$ & $\begin{array}{l}\text { Maximum } \\
\text { Weighted } \\
\text { Score }=20 \\
\text { points }\end{array}$ \\
\hline Nucita, 2009 [12] & 4 & 16 & 3 & 12 & 3 & 12 & 4 & 16 & $-b$ & - \\
\hline Coetsee, 2014 [13] & 3 & 12 & 3 & 12 & - & - & 3 & 12 & - & - \\
\hline $\begin{array}{l}\text { Darcy et al, } 2010 \\
\text { [14] }\end{array}$ & 3 & 12 & 3 & 12 & 3 & 12 & 4 & 16 & 3 & 12 \\
\hline $\begin{array}{l}\text { Ohemeng-Dapaaha } \\
\text { et al, } 2010 \text { [15] }\end{array}$ & 3 & 12 & 3 & 12 & - & - & 2 & 8 & - & - \\
\hline $\begin{array}{l}\text { Tilahun and Fleur, } \\
2015 \text { [16] }\end{array}$ & 2 & 8 & 2 & 8 & 3 & 12 & 2 & 8 & 4 & 16 \\
\hline $\begin{array}{l}\text { Kmadjeu at al, } 2005 \\
{[17]}\end{array}$ & 3 & 12 & 3 & 12 & 3 & 12 & 3 & 12 & 4 & 16 \\
\hline $\begin{array}{l}\text { United Nations De- } \\
\text { velopment Pro- } \\
\text { gramme, } 2014 \text { [18] }\end{array}$ & 3 & 12 & 4 & 16 & - & - & 4 & 12 & 3 & 12 \\
\hline $\begin{array}{l}\text { Mbananga et al, } \\
2002 \text { [19] }\end{array}$ & 3 & 12 & 3 & 12 & - & - & 2 & 8 & - & - \\
\hline $\begin{array}{l}\text { Tierney et al, } 2010 \\
\text { [20] }\end{array}$ & 3 & 12 & 3 & 12 & - & - & 4 & 16 & - & - \\
\hline $\begin{array}{l}\text { Mensah et al, } 2015 \\
\text { [21] }\end{array}$ & 3 & 12 & 3 & 12 & - & - & - & - & 3 & 12 \\
\hline $\begin{array}{l}\text { Haskew et al, } 2015 \\
\text { [22] }\end{array}$ & 5 & 20 & - & - & 4 & 16 & - & - & 3 & 12 \\
\hline $\begin{array}{l}\text { Castelnuovo et al, } \\
2012 \text { [23] }\end{array}$ & 5 & 20 & 3 & 12 & 4 & 16 & 3 & 12 & 3 & 12 \\
\hline $\begin{array}{l}\text { Manders et al, } 2010 \\
\text { [24] }\end{array}$ & 3 & 12 & 3 & 12 & 4 & 16 & 3 & 12 & - & - \\
\hline $\begin{array}{l}\text { Newman et al, } 2011 \\
{[25]}\end{array}$ & 3 & 12 & 4 & 16 & 4 & 16 & 3 & 12 & 3 & 12 \\
\hline $\begin{array}{l}\text { Guylain et al, } 2015 \\
\text { [26] }\end{array}$ & 3 & 12 & - & - & 4 & 16 & - & - & 2 & 8 \\
\hline $\begin{array}{l}\text { Open MRS, } 2015 \\
\text { [27] }\end{array}$ & 3 & 12 & 4 & 16 & 3 & 12 & 3 & 12 & 5 & 20 \\
\hline $\begin{array}{l}\text { Chaplin et al, } 2015 \\
\text { [28] }\end{array}$ & 5 & 20 & 3 & 12 & 4 & 16 & 4 & 16 & 4 & 16 \\
\hline $\begin{array}{l}\text { Amoroso et al, } 2010 \\
\text { [29] }\end{array}$ & 4 & 16 & 4 & 16 & 4 & 16 & 2 & 8 & 3 & 12 \\
\hline $\begin{array}{l}\text { Douglas et al, } 2010 \\
\text { [30] }\end{array}$ & 3 & 12 & - & - & 3 & 12 & 5 & 20 & 4 & 16 \\
\hline
\end{tabular}

${ }^{\mathrm{a} R a t i n g}$ : Excellent=5, Good=4, Fair=3, Poor=2, Bad=1.

${ }^{\mathrm{b}}$ Not applicable. 
Table 6. Overall scoring of the 19 systems on the 5 key metrics.

\begin{tabular}{llllll}
\hline Scores $^{\mathrm{a}}$ & $\begin{array}{l}\text { Effectiveness (19 } \\
\text { systems scored) }\end{array}$ & $\begin{array}{l}\text { Efficiency (16 } \\
\text { systems scored) }\end{array}$ & $\begin{array}{l}\text { Ease of learning (13 } \\
\text { systems scored) }\end{array}$ & $\begin{array}{l}\text { User satisfaction (16 } \\
\text { systems scored) }\end{array}$ & $\begin{array}{l}\text { Cognitive load (13 } \\
\text { systems scored) }\end{array}$ \\
\hline $\begin{array}{l}\text { Total weighted score } \\
\text { Maximum attainable total score (max. }\end{array}$ & 256 & 204 & 184 & 200 & 176 \\
$\begin{array}{l}\text { weight x no. scored) } \\
\text { Percentage score (total/max x 100) }\end{array}$ & $67 \%$ & 320 & 260 & 320 & 260 \\
\hline
\end{tabular}

${ }^{\mathrm{a} O v e r a l l ~ u s a b i l i t y ~ p e r c e n t a g e ~ s c o r e ~}=($ sum of total weighted scores/sum of max attainable scores $) \times 100 \%=66 \%$.

\section{Results}

\section{Effectiveness}

All 19 publications reviewed were rated for effectiveness. Effectiveness was translated to systems being able to enhance patient care and management, provide significant improvement or be indispensable, be effective, meet implementation objectives, improve data quality, improve records availability, or being able to provide decision support to users. From the 19 systems, 3 systems (16\%) obtained a rating of excellent for effectiveness, 2 systems (11\%) obtained a rating of good for effectiveness, whereas 13 systems $(68 \%)$ obtained a rating of fair for effectiveness. 1 system $(5 \%)$ obtained a rating of poor for effectiveness and no system obtained a rating of bad for effectiveness. A majority of the systems reviewed were therefore found to be good in effectively achieving their implementation objectives. The percentage score for effectiveness of all 19 systems was found to be $67 \%$ (SD $1.47 ; 95 \%$ CI).

\section{Efficiency}

In the literature review, efficiency was associated with eliminating delays, reducing patient or provider burden, reducing time, and streamlining procedures or improving workflows. Efficiency was rated for 16 out of the 19 systems reviewed. No system obtained a rating of excellent for efficiency out of all 16 systems. From the 16 systems, 4 systems (25\%) obtained a rating of good for efficiency. The majority of the systems, 11 out of $16(69 \%)$, obtained a rating of fair for efficiency. Furthermore, 1 system $(6 \%)$ obtained a rating of poor for efficiency and no system was found to be bad in efficiency. The percentage score for efficiency of the 16 systems scored was found to be $64 \%$ (SD 1.04).

\section{Ease of Learning}

Ease of learning was associated with quick user proficiency, user-friendly interfaces, easy system comprehension, similarity with paper forms, system ease of learning and use, as well as availability of language customization capabilities in the reviewed EMR systems. A total of 13 out of the 19 systems reviewed were rated for ease of learning. Out of the 13, no system obtained a rating of excellent for ease of learning. The majority of the systems, 7 out of $13(54 \%)$, obtained a rating of good for ease of learning, whereas the rest of the systems, 6 out of $13(46 \%)$, obtained a rating of fair for ease of learning. Ease of learning obtained the highest percentage score of all the 5 key usability metrics with a score of $71 \%$ (SD 1.09).

\section{User Satisfaction}

A total of 16 out of 19 systems reviewed were rated for user satisfaction. User satisfaction was associated with mention that users preferred the system or viewed the system as essential, were happy with or enthusiastic about the system, relied on the system, perceived many benefits from use of the system; there was also little mention of EMR system adoption challenges. Out of the 16,1 system $(6 \%)$ obtained a rating of excellent for user satisfaction. A substantial number of systems, 5 out of 16 (31\%), obtained a rating of good for user satisfaction. The majority of the systems, 6 out of $16(38 \%)$, obtained a rating of fair for user satisfaction. A total of 4 systems (25\%) obtained a rating of poor for user satisfaction and no system obtained a rating of bad for user satisfaction. The percentage score for user satisfaction was the lowest of all the 5 metrics with a score of $63 \%$ (SD 1.70).

\section{Cognitive Load}

A total of 13 out of the 19 systems were rated for cognitive load. Cognitive load was associated with inclusion of standard treatment guidelines, easy discernment of system functionality, well-organized information within the system, logical and systematic documentation within the system, intuitive design of the EMR system, easy access to system information as well as availability of reports within the EMR system. Of the 13 systems, 1 system (8\%) obtained a rating of excellent for cognitive load, whereas 4 systems $(31 \%)$ were rated as having good cognitive load. The majority of the systems, 7 out of 13 $(54 \%)$, obtained a rating of fair for cognitive load. Furthermore, 1 system (8\%) was rated as having poor cognitive load and no system was found to have bad cognitive load. Cognitive load was found to have a percentage score of $68 \%$ (SD 1.62) for the systems reviewed.

\section{Total Scores Per Metric}

The total percentage scores per metric were calculated as indicated in the results section above for each metric and plotted on a radar graph in Figure 2 to visualize their effect on EMR system usability.

\section{Overall Electronic Medical Record Usability Score}

The overall usability score for EMR systems implemented in sub-Saharan Africa was calculated as the sum of the total weighted scores of all 5 metrics divided by the sum of the maximum attainable total scores of all 5 metrics and the result expressed as a percentage. It was found to be $66 \%$. 
Figure 2. Radar graph showing usability of electronic medical record (EMR) systems implemented in sub-Saharan Africa. Ease of Learning has possibly positively influenced usability most.

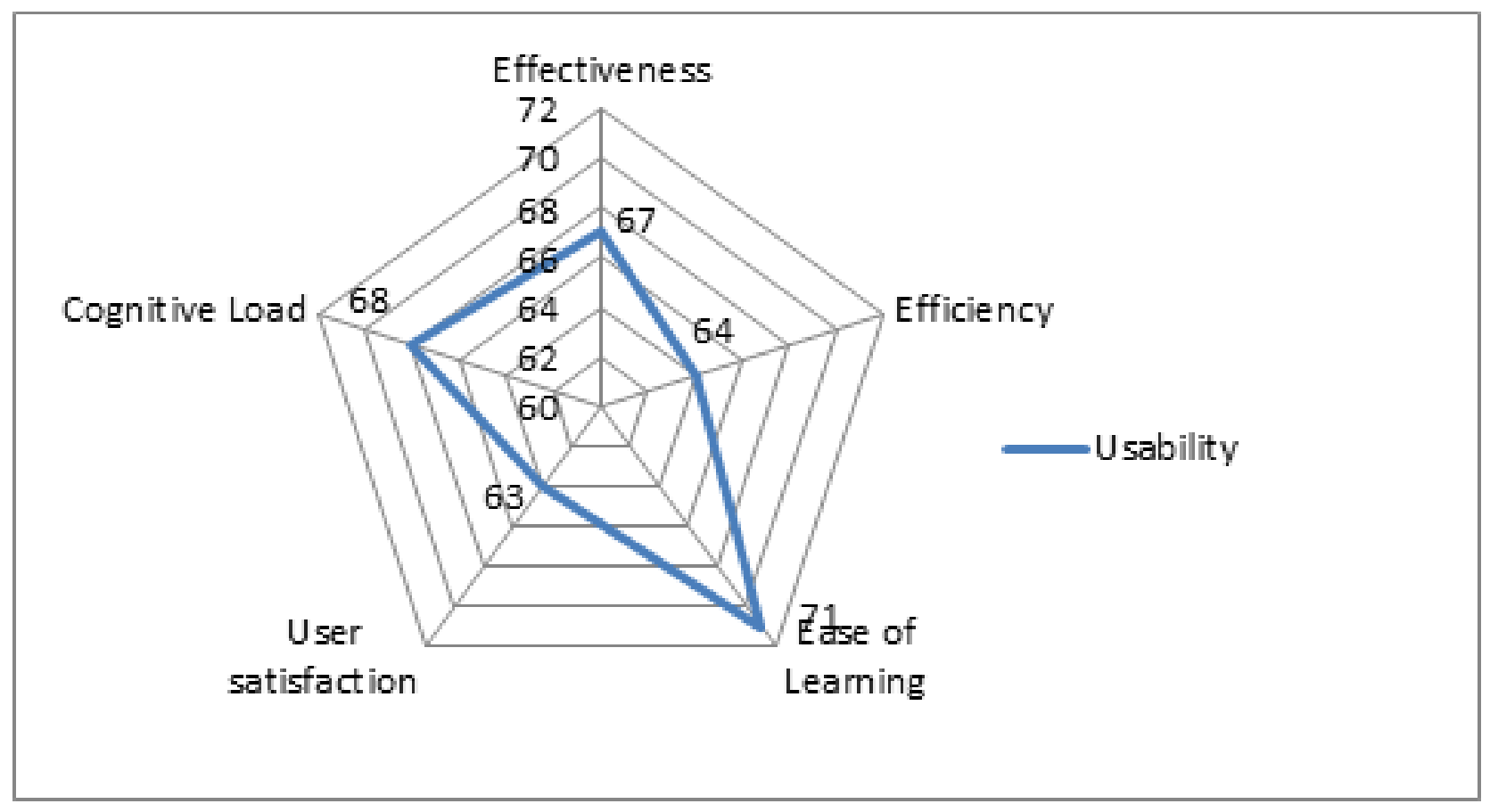

\section{Discussion}

\section{Principal Findings}

The usability of EMR systems implemented in sub-Saharan Africa has been good with an overall score of $66 \%$ across 5 key usability metrics. Ease of learning has possibly had the most positive influence on this rating and was defined for this review as the time it takes a user to reach a specified level of proficiency in the use of an EMR system. It probably has allowed users speedy and easy acquaintance with implemented systems, thereby enhancing their usability.

A relationship was observed between the scores for ease of learning and effectiveness in which a number of systems reviewed simultaneously obtained high scores in both metrics, suggesting that EMR systems might be more effective when they are easy to learn. A slight relationship was also observed between ease of learning and efficiency in which a few of the reviewed systems simultaneously obtained high scores in both metrics.

From the results, cognitive load has possibly contributed the second most to the usability of EMR systems with a percentage score of $68 \%$ (SD 1.62) for systems reviewed across the 5 key usability metrics. Cognitive load for this review was defined by how intuitively information and functionality are presented within the EMR system and appeared to have a slight relationship with user satisfaction.

Following closely in third place with a percentage score of $67 \%$ (SD 1.47) has been effectiveness in potentially positively contributing to EMR system usability in sub-Saharan Africa. Effectiveness was defined as the accuracy and completeness with which a user can achieve task goals within an EMR system, and it was found to have a relationship with ease of learning as described above and a slight relationship with user satisfaction.
Efficiency has probably contributed the second least to positively influencing the usability of EMR systems implemented in sub-Saharan Africa. Efficiency, defined as the speed at which a user can successfully accomplish the task at hand within the EMR system, obtained a percentage score of $64 \%$ (SD 1.04). A slight relationship was observed between efficiency and ease of learning as mentioned above, suggesting that efficiency benefits might be accrued from EMR systems that are easy to learn.

Finally, user satisfaction has probably contributed the least to positively influencing the usability of EMR systems implemented in sub-Saharan Africa. User satisfaction, which was defined as a person's subjective response to his or her interaction with the EMR system, obtained a percentage score of $63 \%$ (SD 1.70). A slight relationship was observed between user satisfaction and effectiveness and user satisfaction and cognitive load as mentioned above, which might imply that where cognitive load is well-incorporated into the EMR system design, the systems are more likely to be effective and users are more likely to accept them.

\section{Conclusions}

This literature review of the usability of EMR systems in sub-Saharan Africa used an evaluation methodology and usability metrics proposed by HIMSS to evaluate the implemented systems through a mixed-methods approach. The review identified that ease of learning has possibly had the most positive influence on the usability of EMR systems implemented in sub-Saharan Africa. Cognitive load and effectiveness have followed closely as second and third potential positive contributors to EMR system usability. Efficiency has possibly contributed the second least and user satisfaction probably contributed the least to EMR system usability. 
Overall, usability appears to have been an enabling factor in the implementation of EMR systems in sub-Saharan Africa as it was found to be good in this review, and the approaches to incorporate usability into EMR implementations ought to prioritize ease of learning of the systems as this has been identified to potentially influence usability most. This supposition that ease of learning with $71 \%$ is the largest impact is true within the $95 \%$ CI because cognitive load at $68 \%+1.62=69.62$ is below $71 \%-1.09=69.91$ and therefore clearly distinct. Easy-to-learn EMR systems are possibly more effective as a relationship between ease of learning and effectiveness was identified in this literature review. Special attention also ought to be paid to user satisfaction while implementing EMR systems as this might not have been given adequate attention among the reviewed systems and therefore possibly contributed the least to the usability of EMR systems implemented in sub-Saharan Africa.

\section{Limitations of the Review}

\section{Methodology Limitations}

This literature review of the usability of EMR systems implemented in sub-Saharan Africa was performed solely by the author and only evaluated EMR systems from publications and documentation about them. No physical evaluation or interaction with the actual systems was carried out as part of this literature review. Therefore, the review had limitations of not evaluating the EMR systems in their production clinical settings. The review also did not interview users of the systems to solicit their opinions on the usability of the systems. Moreover, only EMR system implementations where publications mentioned at least 3 of the 5 key usability metrics developed for this review were included in the final review.

\section{Other Limitations}

The review also equated EMR systems to patient management systems, clinical and hospital information systems, decision support systems, and electronic health record systems, and it did not take into consideration other confounding factors that might have influenced the usability of the reviewed systems such as hardware and related infrastructure, support and technical expertise availability, user engagement, funding, and so on. Therefore, the review only reviewed implemented EMR systems in their already used and published about state with a focus on their usability along the 5 key metrics with all other factors assumed constant.

\section{Acknowledgments}

The author would like to specially acknowledge Professor Maurice Mars of the Department of TeleHealth, University of KwaZulu, Natal, South Africa for his guidance in writing this review article. This work was supported by the National Institute of Health, Fogarty International Centre (grant number: 4D43TW007004).

\section{Conflicts of Interest}

None declared.

\section{Multimedia Appendix 1}

Matching keywords identified in publications for the usability metrics.

[PDF File (Adobe PDF File), 315KB-Multimedia Appendix 1]

\section{References}

1. The Free Dictionary.: Farlex, Inc Electronic Medical Record URL: https://medical-dictionary.thefreedictionary.com/ electronic+medical+record[WebCite Cache ID 76Ktigg Vc]

2. Mackinnon W, Wasserman M. Integrated electronic medical record systems: critical success factors for implementation. In: IEEE.: IEEE; 2009 Presented at: 42nd Hawaii International Conference on System Sciences; Jan 5-8, 2009; Hawaii p. 1-10 URL: https://www.computer.org/csdl/proceedings/hicss/2009/3450/00/06-04-05.pdf [doi: 10.1109/HICSS.2009.264]

3. Shortliffe EH. The evolution of electronic medical records. Acad Med 1999 Apr;74(4):414-419. [Medline: 10219224]

4. Fonquernie F, Lacombe K, Vincensini J, Boccara F, Clozel S, Ayouch Boda A, et al. How to improve the quality of a disease management program for HIV-infected patients using a computerized data system. The Saint-Antoine Orchestra program. AIDS Care 2010 May;22(5):588-596. [doi: 10.1080/09540120903280893] [Medline: 20401768]

5. Ammenwerth E, Schnell-Inderst P, Machan C, Siebert U. The effect of electronic prescribing on medication errors and adverse drug events: a systematic review. J Am Med Inform Assoc 2008;15(5):585-600 [FREE Full text] [doi: 10.1197/jamia.M2667] [Medline: 18579832]

6. Samaan ZM, Klein M, Mansour M, DeWitt TG. The impact of the electronic health record on an academic pediatric primary care center. J Ambul Care Manage 2009;32(3):180-187. [doi: 10.1097/JAC.0b013e3181ac9667] [Medline: 19542807]

7. Holroyd-Leduc JM, Lorenzetti D, Straus S, Sykes L, Quan H. The impact of the electronic medical record on structure, process, and outcomes within primary care: a systematic review of the evidence. J Am Med Inform Assoc 2011;18(6):732-737 [FREE Full text] [doi: 10.1136/amiajnl-2010-000019] [Medline: 21659445]

8. Zlabek JA, Wickus J, Mathiason M. Early cost and safety benefits of an inpatient electronic health record. J Am Med Inform Assoc 2011;18(2):169-172 [FRE Full text] [doi: 10.1136/jamia.2010.007229] [Medline: 21292703] 
9. Fraser HS, Biondich P, Moodley D, Choi S, Mamlin B, Szolovits P. Implementing electronic medical record systems in developing countries. Inform Prim Care 2005;13(2):83-95 [FREE Full text] [Medline: 15992493]

10. Akanbi MO, Ocheke A, Agaba P, Daniyam C, Agaba E, Okeke E, et al. Use of electronic health records in sub-Saharan Africa: progress and challenges. J Med Trop 2012;14(1):1-6 [FREE Full text] [Medline: 25243111]

11. Healthcare Information and Management Systems Society. HIMSS EHR Usability Task Force. 2009 Jun. Defining and Testing EMR Usability: Principles and Proposed Methods of EMR Usability Evaluation and Rating URL: http://www. himss.org/defining-and-testing-emr-usability-principles-and-proposed-methods-emr-usability-evaluation-and [accessed 2017-10-03] [WebCite Cache ID 6twAMg75D]

12. Nucita A, Bernava M, Bartolo M, Masi F, Giglio P, Peroni M, et al. A global approach to the management of EMR (electronic medical records) of patients with HIV/AIDS in sub-Saharan Africa: the experience of DREAM software. BMC Med Inform Decis Mak 2009 Sep 11;9:42 [FREE Full text] [doi: 10.1186/1472-6947-9-42] [Medline: 19747371]

13. Coetsee JL, Kruger TF, Vine D. An electronic health record for infertility clinics. S Afr J OG 2014 Apr 03;20(1):31. [doi: 10.7196/sajog.683]

14. Darcy N, Kelley C, Reynolds E, Cressman G, Killam P. RTI International.: RTI Press; 2010 Mar. An Electronic Patient Referral Application: A Case Study from Zambia URL: http://citeseerx.ist.psu.edu/viewdoc/download?doi=10.1.1.424. 4963\&rep=rep1\&type=pdf [accessed 2016-11-28]

15. Ohemeng-Dapaah S, Pronyk P, Akosa E, Nemser B, Kanter A. Combining vital events registration, verbal autopsy and electronic medical records in rural Ghana for improved health services delivery. Stud Health Technol Inform 2010;160(Pt 1):416-420. [Medline: 20841720]

16. Tilahun B, Fritz F. Comprehensive evaluation of electronic medical record system use and user satisfaction at five low-resource setting hospitals in ethiopia. JMIR Med Inform 2015 May 25;3(2):e22 [FREE Full text] [doi: 10.2196/medinform.4106] [Medline: 26007237]

17. Kamadjeu RM, Tapang M, Moluh N. Designing and implementing an electronic health record system in primary care practice in sub-Saharan Africa: a case study from Cameroon. Inform Prim Care 2005;13(3):179-186 [FREE Full text] [Medline: 16259857$]$

18. UNDP. United Nations Development Programme.: United Nations Development Programme; 2015. Electronic Patient Management System ePMS Zimbabwe URL: https://undp-healthsystems.org/files/capacities/dhis/ epms_zimbabwe_march_2015-web.pdf [accessed 2016-11-27]

19. Mbananga N, Madale R, Becker P. The Medical Research Council of South Africa.: Health Systems Trust; 2002 May. Evaluation of Hospital Information System in the Northern Province in South Africa URL: https://pdfs.semanticscholar.org/ ab97/8903cb3089607cedc1c72343e9d144938807.pdf [accessed 2016-11-19]

20. Tierney W, Achieng M, Baker E, Bell A, Biondich P, Braitstein P, Tanzania-Uganda Openmrs Consortium. Experience implementing electronic health records in three East African countries. Stud Health Technol Inform 2010;160(Pt 1):371-375. [Medline: 20841711]

21. Mensah N, Sukums F, Awine T, Meid A, Williams J, Akweongo P, et al. Impact of an electronic clinical decision support system on workflow in antenatal care: the QUALMAT eCDSS in rural health care facilities in Ghana and Tanzania. Glob Health Action 2015;8:25756 [FREE Full text] [doi: 10.3402/gha.v8.25756] [Medline: 25630707]

22. Haskew J, Rø G, Turner K, Kimanga D, Sirengo M, Sharif S. Implementation of a cloud-based electronic medical record to reduce gaps in the HIV treatment continuum in rural Kenya. PLoS One 2015;10(8):e0135361 [FREE Full text] [doi: 10.1371/journal.pone.0135361] [Medline: 26252212]

23. Castelnuovo B, Kiragga A, Afayo V, Ncube M, Orama R, Magero S, et al. Implementation of provider-based electronic medical records and improvement of the quality of data in a large HIV program in Sub-Saharan Africa. PLoS One 2012;7(12):e51631 [FREE Full text] [doi: 10.1371/journal.pone.0051631] [Medline: 23284728]

24. Manders EJ, José E, Solis M, Burlison J, Nhampossa J, Moon T. Implementing OpenMRS for patient monitoring in an HIV/AIDS care and treatment program in rural Mozambique. Stud Health Technol Inform 2010;160(Pt 1):411-415. [Medline: 20841719]

25. Newman J, Torres P, Azinyue I, Hemingway-Foday J, Atibu J, Akam W, et al. Improvement of service capabilities following the establishment of an electronic database to evaluate AIDS in Central Africa. J Health Inform Dev Ctries 2011 Jul 22;5(2):273-285 [FREE Full text]

26. Guylain V, Mubaraka C, Salisu M. Global Journal of Engineering, Design and Technology. 2013. Integration of ICT in health service management in HEAL Africa hospital in DRCongo URL: https://www.longdom.org/articles/ integration-of-ict-in-health-service-management-in-heal-africa-hospital-in-drcongo.pdf [accessed 2019-02-17] [WebCite Cache ID 76G2CDzaG]

27. OpenMRS. 2016 Aug 31. OpenMRS Ebola Case Study: Fighting Ebola with Open Source Collaboration URL: https:/ lopenmrs.org/2016/08/openmrs-ebola-case-study/ [accessed 2016-11-30]

28. Chaplin B, Meloni S, Eisen G, Jolayemi T, Banigbe B, Adeola J, et al. Scale-up of networked HIV treatment in Nigeria: creation of an integrated electronic medical records system. Int J Med Inform 2015 Jan;84(1):58-68. [doi:

10.1016/j.ijmedinf.2014.09.006] [Medline: 25301692] 
29. Amoroso CL, Akimana B, Wise B, Fraser HS. Using electronic medical records for HIV care in rural Rwanda. Stud Health Technol Inform 2010;160(Pt 1):337-341. [doi: 10.3233/978-1-60750-588-4-337] [Medline: 20841704]

30. Douglas GP, Gadabu O, Joukes S, Mumba S, McKay M, Ben-Smith A, et al. Using touchscreen electronic medical record systems to support and monitor national scale-up of antiretroviral therapy in Malawi. PLoS Med 2010 Aug 10;7(8) [FREE Full text] [doi: 10.1371/journal.pmed.1000319] [Medline: 20711476]

\author{
Abbreviations \\ EMR: electronic medical record \\ HIMSS: Healthcare Information and Management Systems Society
}

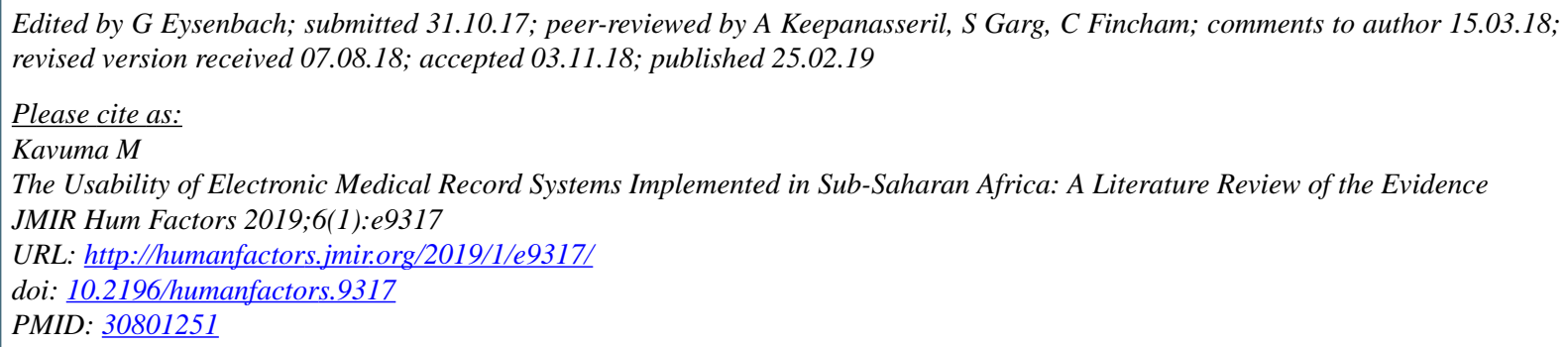

CMichael Kavuma. Originally published in JMIR Human Factors (http://humanfactors.jmir.org), 25.02.2019. This is an open-access article distributed under the terms of the Creative Commons Attribution License (https://creativecommons.org/licenses/by/4.0/), which permits unrestricted use, distribution, and reproduction in any medium, provided the original work, first published in JMIR Human Factors, is properly cited. The complete bibliographic information, a link to the original publication on http://humanfactors.jmir.org, as well as this copyright and license information must be included. 